\title{
PENGEMBANGAN LEMBAR KERJA SISWA DENGAN PENDEKATAN SAINTIFIK BERBASIS KEMAMPUAN PEMECAHAN MASALAH
}

\author{
Nora Septina'; Farida ${ }^{2}$; Komarudin ${ }^{3}$ \\ ${ }^{123}$ UIN Raden Intan Lampung, Bandar Lampung, Indonesia \\ 1Septinanora@gmail.com, 2farida@radenintan.ac.id,3qhomar8@gmail.com
}

\begin{abstract}
Abstrak
Penelitian ini merupakan penelitian pengembangan yang bertujuan untuk menghasilkan produk berupa Lembar Kerja Peserta Didik (LKPD) dengan pendekatan saintifik berbasis kemampuan pemecahan masalah matematika. Prosedur penelitian dan pengembangan yang digunakan adalah model pengembangan Borg dan Gall yang dimodifikasi oleh sugiyono. Instrumen pengumpulan data yang digunakan adalah angket yang diberikan kepada para ahli untuk mengetahui kelayakan produk dan angket yang diberikan kepada peserta didik dan pendidik untuk mengetahui kemenarikan produk. Hasil penelitian menunjukkan bahwa penilaian dari para ahli sangat layak ( $86 \%$ ahli materi, dan $85 \%$ ahli media), respon peserta didik dan pendidik sangat menarik (88\% uji coba kelompok kecil, $89 \%$ uji coba lapangan dan $88 \%$ uji coba pendidik).
\end{abstract}

Kata kunci: Lembar Kerja Peserta Didik; Pendekatan Saintifik; Kemampuan Pemecahan Masalah;

\begin{abstract}
The current study is a development research aiming to produce scientific-approach student work sheet which is based on mathematical problem solving ability. Borg and Gall development model modified by sugiyono is utilized in this study. Questionnaire is given to experts to find out the feasibility of the product and to learners and educators to know the attractiveness of the product. The results of the study indicates that the assessment of the experts is very feasible ( $83 \%$ of material experts, and $85 \%$ of media experts), the response of learners and educators is very interesting (88\% small group trial, $89 \%$ field trials and $88 \%$ educator test) .

Keywords: Student Work Sheet; Scientific Approach; ProblemSolving Abilities;
\end{abstract}

\section{PENDAHULUAN}

Pendidikan merupakan upaya dalam menyiapkan seorang manusia melalui kegiatan bimbingan, pengajaran, dan latihan yang diharapkan dapat berguna bagi perannya dimasa yang akan datang(Agustiana, Putra, \& Farida, 2018). Di dalam undang-undang juga dijelaskan bahwa setiap penduduk berhak mendapatkan pendidikan yang bermutu(Supriadi \& Damayanti, 2016). 
Oleh karena itu, dunia pendidikan memerlukan inovasi-inovasi yang sesuai dengan kemajuan ilmu pengetahuan dan teknologi tanpa mengabaikan nilainilai kemanusiaan.Untuk meningkatkan mutu pendidikan di Indonesia salah satu upaya pemerintah adalah memperbaiki kurikulum pendidikan dari berbagai jenjang. Salah satu bentuk perbaikan kurikulum pendidikan saat ini adalah dengan berlakunya kurikulum 2013, dimana kurikulum ini dikembangkan berdasarkan tantangan baik internal maupun eksternal sehingga tujuan pendidikan dapat direalisasikan. Salah satu penekanan dalam Kurikulum 2013 adalah pengembangan kemampan siswa dalam pemecahan masalah.

Pada aspek kemampuan pemecahan masalah, siswa Indonesia secara umum memiliki kemampuan pemecahan masalah yang kurang memadai. Studi awal di SMP Negeri 1 Liwa diperoleh informasi bahwa pemecahan masalah matematika masih rendah. Salah satu penyebab lemahnya kemampuan pemecahan masalah siswa adalah belum tersedianya lembar kerja siswa yang menekankan pada kegiatan percobaan dan observasi yang berdasarkan pendekatan saintifik. Oleh karena itu, diperlukan suatu media pembelajaranyang sesuai dengan untuk memupuk dan menumbuhkan sikap ilmiah peserta didik.

Memperhatikan peranan penting dari lembar kerja siswa untuk mencapai tujuan pembelajaran, peneliti kependidikan memberikan perhatian yang intensif terhadap pengembangan lembar kerja siswa. Berbagai penelitian pengembangan lembar kerja siswa telah dilakukan, seperti pengembangan lembar kerja siswa tematik-integratif berbasis pendidikan karakter (Sasmito \& Mustadi, 2015), pengembangan lembar kerja siswa berbasis pendekatan saintifik berbasis pemecahan masalah(Nurliawaty, Mujasam, Yusuf, \& Widyaningsih, 2017), Pengembangan lembar kerja siswa berorientasi nilainilai Islami (Latifah, 2016; Munandar, Yusrizal, \& Mustanir, 2017), dansebagainya. 
Berdasarkan penelitian sebelumnya yang telah dipaparkan di atas, maka dalam penelitian ini peneliti tertarik melakukan sebuah penelitian yaitu mengembangkan lembar kerja siswa dengan pendekatan saintifik berbasis kemampuan pemecahan masalah matematika pada materi operasi hitung bentuk aljabar. Pendekatan saintifik yaitu pendekatan yang proses pembelajarannya di rancang sedemikian rupa agar peserta didik dapat lebih aktif serta dapat berpikir sistematis dan kritis dalam upaya pemecahan masalah.

\section{LANDASAN TEORI}

Pendekatan saintifik dalam penelitian ini adalah suatu proses pembelajaran yang telah dirancang sedemikian rupa agar peserta didik dapat aktif membangun konsep, hokum atau prinsip melalui tahapan-tahapan mengamati, merumuskan masalah, merumuskan hipotesis, mengumpulkan data dengan bermacam-macam teknik, menganalisis data, menarik kesimpulan dan mengkomunikasikan konsep, hokum atau prinsip yang ditemukan (Hosnan, 2014). Pembelajaran dengan pendekatan saintifik merupakan pembelajaran yang menuntut peserta didik berpikir sistematis dan kritis dalam upaya pemecahan masalah yang penyelesaiannya tidak mudah dilihat (Abidin.Y., 2013). Adapun langkah kegiatan atau proses pembelajaran menggunakan pendekatan saintifik digambarkan pada Tabel 1.

\section{Tabel 1.}

Langkah kegiatan atau proses pembelajaran Menggunakan pendekatan saintifik

\begin{tabular}{lll}
\hline $\begin{array}{c}\text { Langkah } \\
\text { Pembelajaran }\end{array}$ & \multicolumn{1}{c}{ Kegiatan Belajar } & \multicolumn{1}{c}{$\begin{array}{c}\text { Kompetensi Yang } \\
\text { Dikembangkan }\end{array}$} \\
\hline Mengamati & $\begin{array}{l}\text { Membaca, Mendengar, } \\
\text { melihat }\end{array}$ & $\begin{array}{l}\text { Melatih Peserta Didik } \\
\text { dalam ketelitian dan } \\
\text { mencari informasi }\end{array}$ \\
Menanya & $\begin{array}{l}\text { Mengajukan pertanyaan } \\
\text { tentang informasi yang } \\
\text { tidak dipahami dari apa } \\
\text { yang diamati atau }\end{array}$ & $\begin{array}{l}\text { Mengembangkan } \\
\text { kreatifitas, rasa ingin tahu, } \\
\text { kemampuan merumuskan }\end{array}$ \\
& &
\end{tabular}




\begin{tabular}{|c|c|c|}
\hline & $\begin{array}{l}\text { pertanyaan untuk } \\
\text { mendapatkan informasi } \\
\text { tambahan tentang apa } \\
\text { yang diamati }\end{array}$ & $\begin{array}{l}\text { pertanyaan untuk } \\
\text { membentuk pikiran kritis }\end{array}$ \\
\hline $\begin{array}{l}\text { Mengumpulkan } \\
\text { informasi } \\
\text { (Mencoba) }\end{array}$ & Melakukan eksperimen & $\begin{array}{l}\text { Mencoba untuk } \\
\text { meningkatkan rasa ingin } \\
\text { tahu peserta didik dalam } \\
\text { mengembangkan } \\
\text { kreatifitas, dapat } \\
\text { dilakukan melalui } \\
\text { membaca, ,mengamati } \\
\text { kejadian atau objek } \\
\text { tertentu }\end{array}$ \\
\hline $\begin{array}{l}\text { Mengasosiasi } \\
\text { (Menalar) }\end{array}$ & $\begin{array}{l}\text { Mengolah informasi yang } \\
\text { sudah dikumpulkan dari } \\
\text { hasil kegiatan } \\
\text { eksperimen maupun } \\
\text { hasil dari kegiatan } \\
\text { mengamati dan kegiatan } \\
\text { mengumpulkan } \\
\text { informasi }\end{array}$ & $\begin{array}{l}\text { Mengembangkan sikap } \\
\text { teliti, dan kemampuan } \\
\text { menerapkan prosedur dan } \\
\text { kemampuan berpikir } \\
\text { dalam menyimpulkan }\end{array}$ \\
\hline $\begin{array}{l}\text { Mengkomunikasi } \\
\text { kan }\end{array}$ & $\begin{array}{l}\text { Menyampaikan hasil } \\
\text { pengamatan, kesimpulan } \\
\text { berdasarkan hasil } \\
\text { analisis secara lisan, } \\
\text { tulisan atau media } \\
\text { lainnya }\end{array}$ & $\begin{array}{l}\text { Mengembangkan sikap } \\
\text { teliti dan } \\
\text { mengembangakan } \\
\text { kemampuan berpikir } \\
\text { sistematis serta } \\
\text { mengungkapkan } \\
\text { pendapat. }\end{array}$ \\
\hline
\end{tabular}

Dalam penelitian ini, definisi kemampuan pemecahan masalah merujuk pada pandangan Ormrod, yaitu kemampuan pemecahan masalah adalah kemampuan menggunakan pengetahuan dan keterampilan yang sudah ada untuk menjawab pertanyaan yang belum terjawab atau situasi yang sulit (Widyastuti, 2015).

\section{METODE}

Jenis penelitian ini adalah penelitian pengembangan. Prosedur pengembangan yang digunakan adalah metode Borg and Gall (Sugiyono, 2015) 
yang menjelaskan 10 tahapan langkah dari metode Borg and Gall. Namun dalam penelitian ini, peneliti hanya membatasi langkah-langkah penelitian pengembangan dari sepuluh langkah menjadi tujuh langkah. Penelitian yang dilakukan tidak sampai pada tahap uji pemakaian dan produksi masal dari produk yang sudah dihasilkan karena peneliti hanya melihat dari kelayakan produk berdasarkan hasil penilaian dari validator serta melihat respon pendidik dan peserta didik terhadap lembar kerja siswa yang telah dikembangkan. Secara umum, prosedur pengembangan produk dalam penelitian ini, yaitu analisis potensi dan masalah, pengumpulan data, desain produk, validasi desain, perbaikan desain, uji coba produk, dan revisi produk.

Teknik Pengumpulan data yang dilakukanya itu dengan, wawancara dan penyebaran angket skala likert dengan 5 jawaban. Penskoran yang digunakan dalam penilaian validasi ahli dapat dilihat pada Tabel 2. Sedangkan penskoran uji kemenarikan produk dapat dilihat pada Tabel 3.

Tabel 2.

Skor presentase penilaian validasi para ahli

\begin{tabular}{ll}
\hline \multicolumn{1}{c}{ Penilaian } & \multicolumn{1}{c}{ Kriteria Interpretasi } \\
\hline $81 \% \leq P \leq 100 \%$ & Sangat Layak \\
$61 \% \leq P<81 \%$ & Layak \\
$41 \% \leq P<61 \%$ & Cukup Layak \\
$21 \% \leq P<41 \%$ & Tidak Layak \\
$0 \% \leq P<21 \%$ & Sangat Tidak Layak \\
\hline
\end{tabular}

Tabel 3.

Skor presentase uji kemenarikan peserta didik

\begin{tabular}{ll}
\hline \multicolumn{1}{c}{ Penilaian } & \multicolumn{1}{c}{ Kriteria Interpretasi } \\
\hline $81 \% \leq P \leq 100 \%$ & Sangat Menarik \\
$61 \% \leq P<81 \%$ & Menarik \\
$41 \% \leq P<61 \%$ & Cukup Menarik \\
$21 \% \leq P<41 \%$ & Tidak Menarik \\
$0 \% \leq P<21 \%$ & Sangat Tidak Menarik \\
\hline
\end{tabular}

Skor penilaian total dalam analisa data dapat dicari dengan rumus berikut: $\mathrm{P}=\frac{\mathrm{F}}{\mathrm{N}} \times 100 \%$ dengan $\mathrm{P}$ adalah angka presentase data angket, $\mathrm{F}$ adalah jumlah skor yang diperoleh, dan $\mathrm{N}$ adalah Jumlah skor maksimum. 


\section{HASIL DAN PEMBAHASAN}

Penelitian ini menghasilkan sebuah lembar kerja siswa dengan pendekatan saintifik berbasis kemampuan pemecahan masalah matematika. Produk akhir dari penelitian ini dapat diakses melalui https://drive.google.com/open?id=0B0BuiqNX0-h2X2tVb3p4b3JPM0JGaTlS VVdiOFVWQ3p1Q2JZ.

Tahapan yang digunakan dalam penelitian dan pengembangan ini menggunakan prosedur Borg and Gall 7 tahapandari 10 tahapan. Tahapan tahapan itu diantaranya :

a. Potensi dan masalah

Potensi dalam peneliti pengembangan ini adalah mengembangkan LKPD dengan pendekatan saintifik berbasis kemampuan pemecahan masalah matematika pada materi operasi hitung bentuk aljabar kelas VIII SMP. Penelitian ini dilakukan di SMP N 1 Liwa Lampung Barat. Pada mata pelajaran matematika kelas VIII telah menerapkan Kurikulum 2013 dalam kegiatan proses pembelajaran. Proses pengembangan produk tersebut berguna untuk meminimalisir permasalahan di kelas bahwa sudah ada LKPD tetapi belum memasukkan pendekatan saintifik. Pada tahap ini penting dilakukan adalah analisis kebutuhan terhadap produk yang akan dikembangkan melalui wawancara terhadap pendidik Matematika kelas VIII SMP N 01 Liwa Lampung Barat.

b. Pengumpulan Data

Setelah potensi dan masalah diidentifikasi, selanjutnya dilakukan pengumpulan data. Pengumpulan data sangatlah penting untuk mengetahui kebutuhan dari peserta didik terhadap produk yang akan dikembangkan. Tahap awal yang dilakukan adalah mengumpulkan masalah yang ada di SMPN 01 Liwa kepada pendidik dan peserta didik khususnya kelas VIII pada mata pelajaran Matematika yang berupa hasil wawancara. Tahap selanjutnya adalah mengumpulkan sumber-sumber referensi seperti jurnal Matematika yang sangat berkaitan dengan Pengembangan LKPD dengan Pendekatan 
Saintifik berbasis Kemampuan Pemecahan Masalah Matematika dan buku matematika kelas VIII kurikulum 2013.

\section{c. Desain Produk}

Setelah melakukan penelitian dan pengumpulan data yang dibutuhkan, peneliti melakukan rencana awal dalam membuat produk berupa LKPD dengan pendekatan saintifik berbasis kemampuan pemecahan masalah matematika pada materi operasi hitung bentuk aljabar. Penyusunan desain LKPD ini diantaranya yaitu menyesuaikan kompetensi inti dan kompetensi dasarnya berdasarkan kurikulum 2013. LKPD dengan menggunakan pendekatan saintifik berbasis kemampuan pemecahan masalah matematika pada materi operasi hitung bentuk aljabar ini menggunakan ukuran kertas A4, skala spasi 1,15; jenis huruf Time New Roman, Cambria, Matura MT Script Capitals, Bauhaus dan viner hand STC. Adapun desain produk pengembangan LKPD terdiri dari: bagian awal LKPD, bagian isi LKPD, dan bagian penutup.

\section{d. Validasi Desain}

Setelah desain produk selesai, kemudian dilakukan penilaian oleh para ahli materi dan Ahli media. Dari masing-masing penilaian yang diberikan oleh validator ahli, media pembelajaran yang dikembangkan dinyatakan valid dan layak digunakan sebagai media pembelajaran setelah dilakukan revisi. Untuk hasil validasi dapat dilihat padaTabel 3.

Tabel 3.

Hasil validasi ahli materi sebelum dan sesudah revisi

\begin{tabular}{llcccc}
\hline No & \multicolumn{1}{c}{ Aspek } & $\begin{array}{c}\text { Skor } \\
\text { perolehan } \\
\text { sebelum } \\
\text { revisi (\%) }\end{array}$ & Kriteria & $\begin{array}{c}\text { Skor perolehan } \\
\text { sesudah revisi }\end{array}$ & Kriteria \\
(\%) & & \\
\hline 1 & Kelayakan isi & $68 \%$ & Layak & $84 \%$ & Sangat Layak \\
2 & Kelayakan Penyajian & $71 \%$ & Layak & $85 \%$ & Sangat Layak \\
3 & $\begin{array}{l}\text { Pendekatan Saintifik } \\
\text { Kemampuan }\end{array}$ & $80 \%$ & Layak & $93 \%$ & Sangat Layak \\
\hline & $\begin{array}{l}\text { Pemecahan masalah } \\
\text { Matematika }\end{array}$ & $60 \%$ & Layak & $80 \%$ & Sangat Layak \\
\hline
\end{tabular}




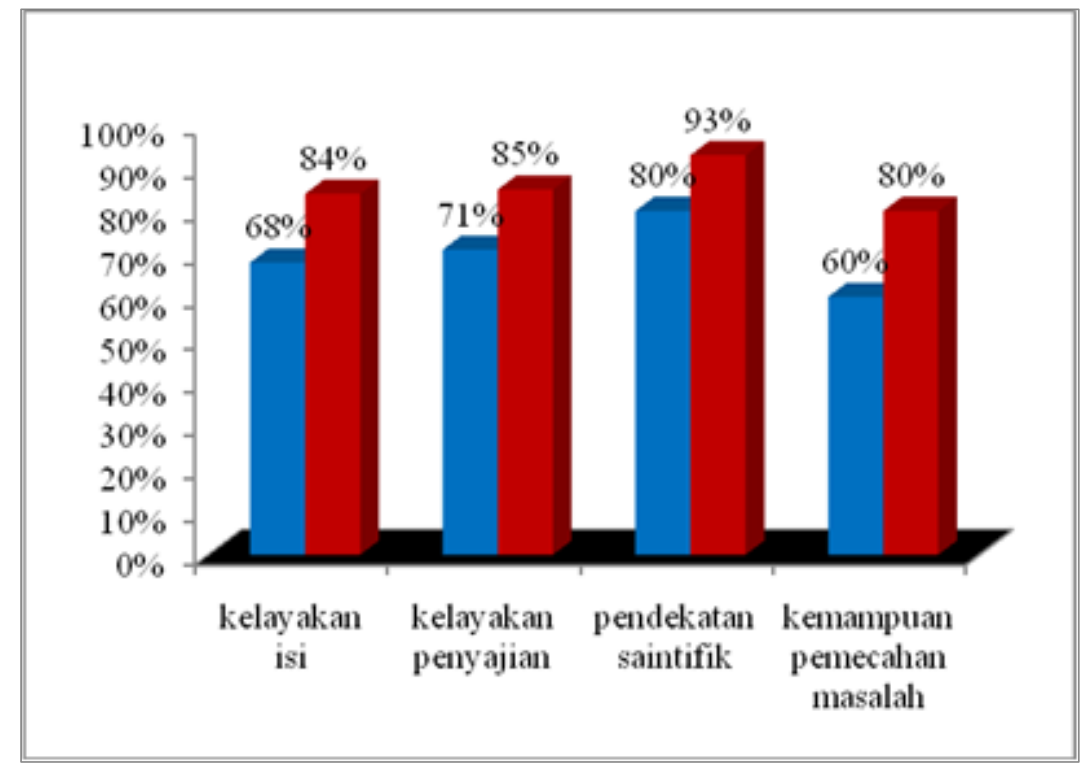

Diagram 1.

Hasil persentase validasi ahli materi sesudah dan sebelum revisi.

Diagram di atas menggambarkan hasil dari validasi ahli materi terhadap produk pada tahap 1 dan tahap 2. Pada setiap komponen yaitu komponen kelayakan isi, kelayakan penyajian, pendekatan saintifik dan kemampuan pemecahan masalah matematika mengalami peningkatan persentase pada tahap 2. Terlihat bahwa, masukan dan saran dari para validator ahli materi memberikan pengaruh terhadap pengembangan produk.

Pada validasi produk yang telah dikembangkan kepada ahli media guna melihat tampilan design produk. Hasil validasi kepada paraahli media dapat dilihat pada Tabel 4 .

Tabel 4.

Hasil validasi oleh ahli media sebelum dan sesudah revisi

\begin{tabular}{cccccc}
\hline No & Aspek & $\begin{array}{c}\text { Skor } \\
\text { perolehan } \\
\text { sebelum revisi }\end{array}$ & Kriteria & $\begin{array}{c}\text { Skor } \\
\text { perolehan } \\
\text { sesudah revisi }\end{array}$ & kriteria \\
\hline 1 & $\begin{array}{l}\text { Kelayakan } \\
\text { Kegrafikan }\end{array}$ & $69 \%$ & Layak & $85 \%$ & Sangat Layak \\
\hline
\end{tabular}




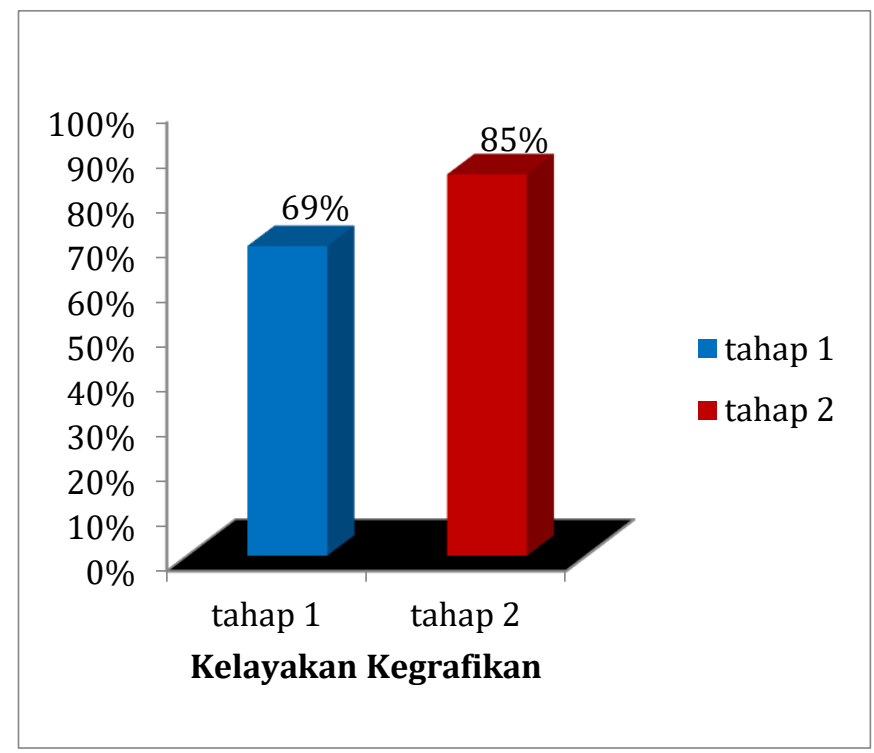

Diagram 2.

Hasil presentase validasi ahli media sesudah dan sebelum revisi

Diagram tersebut menggambarkan hasil validasi dari ahli media terhadap produk yang dikembangkan pada tahap 1 dan tahap 2. Pada komponen kelayakan kegrafikan tahap 1 memperoleh persentase sebesar 69\% sedangkan pada tahap 2 memperoleh persentase sebesar 85\%, terjadi peningkatan persentase pada tahap 2. Dengan demikian, masukan dan saran dari para validator ahli materi memberikan pengaruh terhadap produk yang dikembangkan.

\section{e. Revisidesain}

Setelah dilakukan validasi produk tahap 1 oleh para ahli materi, dan ahli media, terdapat banyak masukan dan saran yang diberikan oleh para ahli terhadap produk yang dikembangkan. Sehingga dilakukan revisi produk sesuai masukan dan saran dari para ahli agar produk yang dikembangkan menjadi produk yang sangat layak dan diap untuk diuji cobakan.

f. Uji coba Produk

Uji coba produk dilakukan pada uji coba kelompok kecil yang terdiri dari 10 peserta didik, uji coba kelompok besar (uji coba lapangan) yang terdiri dari 30 peserta didik sebagai berikut: 
Tabel 5.

Hasil uji coba modul matematika berbasis soal-soal PISA

\begin{tabular}{lccl}
\hline Kelompok uji coba & Jumlah responden & Skor perolehan (\%) & Kriteria \\
\hline Kelompok kecil & 10 & $88 \%$ & Sangat menarik \\
Kelompok besar & 30 & $89 \%$ & Sangat menarik \\
\hline
\end{tabular}

Pada pengujian data yang ditampilkan dalam tabel 5, tingkat kemenarikan produk pada uji coba kelompok kecil memperoleh skor rata-rata 88\% dengan kriteria "Sangat Menarik" dan uji coba kelompok besar mencapai skor rata-rata 89\% dengan kriteria "Sangat Menarik". Dalam hal ini peneliti menyimpulkan bahwa ada kemenarikan tersendiri pembelajaran dengan bantuan media pembelajaran di dalam kelas.

g. Revisi produk

Setelah dilakukan uji coba kelompok kecil, uji coba lapangan, diketahui bahwa LKPD matematika operasi hitung bentuk aljabar dengan pendekatan saintifik berbasis kemampuan pemecahan masalah matematika memperoleh kriteria interpretasi "Sangat Menarik", maka dapat dikatakan bahwa LKPD ini telah selesai dikembangan sehingga menghasilkan produk akhir.

\section{KESIMPULAN}

LKPD dengan pendekatan saintifik berbasis kemampuan pemecahan masalah matematika kelas VIII SMP pada materi operasi hitung bentuk aljabar yang dihasilkan telah dikembangkan menggunakan model Borg and Gall yang dimodifikasi oleh Sugiyono yang meliputi 7 tahapan yaitu, potensi dan masalah, pengumpulan data, desain produk, validasi desain, revisi desain, uji coba produk, dan revisi produk. Respon peserta didik terhadap LKPD pada uji kelompok kecil diperoleh rata-rata skor 88\% dengan kriteria sangat menarik dan pada uji kelompok besar diperoleh skor $87 \%$ dengan kriteria sangat menarik. Respon pendidik terhadap LKPD diperoleh skor 88\% dengan kriteria sangat menarik.

LKPD dengan pendekatan saintifik berbasis kemampuan pemecahan masalah matematika kelas VIII SMP ini hanya menyajikan materi operasi 
Septina, N., Farida, F., \& Komarudin, K. (2018). PENGEMBANGAN LEMBAR KERJA SISWA DENGAN PENDEKATAN SAINTIFIK BERBASIS KEMAMPUAN PEMECAHAN MASALAH. Jurnal Tatsqif, 16(2). Retrieved from http://journal.uinmataram.ac.id/index.php/tatsqif/article/view/200

hitung bentuk aljabar untuk beberapa sub bab saja sehingga diharapkan untuk pengembangan LKPD dengan pendekatan saintifik berbasis kemampuan pemecahan masalah matematika kelas VIII SMP dapat dikembangkan dengan materi yang lebih luas.LKPD ini juga masih banyak kekurangan dalam pembuatan dan pengembangannya, sehingga pengembangan LKPD selanjutnya dapat dikembangkan lebih baik lagi, agar dapat membuat motivasi dan dapat menambah minat peserta didik dalam mengikuti pelajaran matematika dengan aktif.

\section{DAFTAR PUSTAKA}

Abidin.Y. (2013). Desain Sistem Pembelajaran dalam Konteks Kurikulum. Bandung: Rafika Aditama.

Agustiana, E., Putra, F. G., \& Farida, F. (2018). Penerapan Model Pembelajaran Auditory, Intellectually, Repetition (AIR) dengan Pendekatan Lesson Study terhadap Kemampuan Pemecahan Masalah Matematis Peserta Didik. Desimal: Jurnal Matematika, 1(1), 1-6.

Hosnan. (2014). Pendekatan Saintifik dan kontekstual dalam pembelajaran abad 21. Bogor: Ghalia Indonesia.

Latifah, S. (2016). Pengembangan Lembar Kerja Peserta Didik (LKPD) Berorientasi Nilai-Nilai Agama Islam melalui Pendekatan Inkuiri Terbimbing pada Materi Suhu dan Kalor. Jurnal Ilmiah Pendidikan Fisika Al-Biruni, 5(1), 43-51.

Munandar, H., Yusrizal, Y., \& Mustanir, M. (2017). Pengembangan Lembar Kerja Peserta Didik (Lkpd) Berorientasi Nilai Islami Pada Materi Hidrolisis Garam. Jurnal Pendidikan Sains Indonesia, 3(1), 27-37.

Nurliawaty, L., Mujasam, M., Yusuf, I., \& Widyaningsih, S. W. (2017). LEMBAR KERJA PESERTA DIDIK (LKPD) BERBASIS PROBLEM SOLVING POLYA. JPI (Jurnal Pendidikan Indonesia), 6(1), 72-81.

Sasmito, L. F., \& Mustadi, A. (2015). Pengembangan Lembar Kerja Peserta Didik Tematik-integratif Berbasis Pendidikan Karakter Pada Peserta 
Septina, N., Farida, F., \& Komarudin, K. (2018). PENGEMBANGAN LEMBAR KERJA SISWA DENGAN PENDEKATAN SAINTIFIK BERBASIS KEMAMPUAN PEMECAHAN MASALAH. Jurnal Tatsqif, 16(2). Retrieved from http://journal.uinmataram.ac.id/index.php/tatsqif/article/view/200

Didik Sekolah Dasar. Jurnal Pendidikan Karakter, (1). Diambil dari https://www.neliti.com/publications/120775/pengembanganlembar-kerja-peserta-didik-tematik-integratif-berbasis-pendidikan-k Sugiyono. (2015). metode penelitian kuantitatif dan kualitatif dan $R \& D$. Bandung: alfabeta.

Supriadi, N., \& Damayanti, R. (2016). Analisis Kemampuan Komunikasi Matematis Siswa Lamban Belajar dalam Menyelesaikan Soal Bangun Datar. Al-Jabar: Jurnal Pendidikan Matematika, 7(1), 1-9.

Widyastuti, R. (2015). Proses Berpikir Siswa dalam Menyelesaikan Masalah Matematika berdasarkan Teori Polya ditinjau dari Adversity Quotient Tipe Climber. Al-Jabar: Jurnal Pendidikan Matematika, 6(2), 183-194. 